\title{
Probiotics and Oral Health
}

\author{
Anna Haukioja $a^{a, b}$
}

\section{ABSTRACT}

The number of products containing probiotics, viable bacteria with proven health benefits, entering the market is increasing. Traditionally, probiotics have been associated with gut health, and most clinical interest has been focused on their use for prevention or treatment of gastrointestinal infections and diseases; however, during the last decade several investigators have also suggested the use of probiotics for oral health purposes. The aim of this review is to examine potential mechanisms of probiotic bacteria in the oral cavity and summarize observed effects of probiotics with respect to oral health. The review focuses on probiotic lactobacilli and bifidobacteria, genera that are most used in various probiotic products. (Eur J Dent 2010;4:348-355)

Key words: Probiotics; Oral health; Lactobacillus; Bifidobacterium.

\section{INTRODUCTION}

Probiotics can be defined as living microbes, or as food ingredients containing living microbes, that beneficially influence the health of the host when used in adequate numbers. ${ }^{1}$ Both definitions have in common the idea that probiotic microorganisms are living. Furthermore, the efficacy and safety of probiotics should be scientifically proven. Probiotic effects are strain specific; thus each individual bacterial strain must be tested separately for the health benefit in question, and the effects described for one strain cannot be directly applied to others. ${ }^{2}$

Traditionally, probiotics have been associated with gut health, and most clinical interest has fo-

\footnotetext{
a Institute of Dentistry, University of Turku, Turku, Finland.

${ }^{b}$ National Institute for Health and Welfare (THL), FI-00300 Helsinki, Finland.

- Corresponding author: Anna Haukioja (PhD) Institute of Dentistry, Lemminkäisenkatu2, Turku, 20520, Finland Tel: + 358440110234

Fax: + 35823338356

E-mail: anna.haukiojadutu.fi
}

cused on the prevention or treatment of gastrointestinal infections and diseases; however, during the last decade, an increasing number of established and proposed health effects of probiotic bacteria have been reported, including enhancement of the adaptive immune response, treatment or prevention of urogenital and respiratory tract infections, and prevention or alleviation of allergies and atopic diseases in infants. ${ }^{2,3}$ Several investigators have also suggested probiotics for oral health purposes. Interestingly, probiotics are also suggested to increase the lifetime of voice prosthesis by inhibiting the adhesion of unwanted microbes. $^{4-6}$

The most commonly used probiotic bacterial strains belong to the genera Lactobacillus and Bifidobacterium. ${ }^{3}$ These bacterial genera are regarded as a part of the normal human microbiota. In the oral cavity, lactobacilli usually comprise fewer than $1 \%$ of the total cultivable microbiota, but no species specific to the oral cavity has been found. In contrast, some species are found in both oral and fecal samples. ${ }^{7.8}$ Species commonly isolated 
from saliva samples include $L$. paracasei, $L$. plantarum, L. rhamnosus, and L. salivarius. ${ }^{7-10}$ Culturebased studies suggest that bifidobacteria are among the first anaerobes in the oral cavity. ${ }^{11} \mathrm{In}$ deed, both lactobacilli and bifidobacteria can be found in breast milk, suggesting early exposure of the oral cavity to these bacteria. ${ }^{12,13}$ Bifidobacterial species isolated from oral samples include $B$. bifidum, B. dentium, and B. longum. $8,14,15$

Lactobacilli and bifidobacteria are generally regarded as safe, and, since the early writing of Metchnikoff, ${ }^{16}$ even more fermented food products have been associated with health benefits. In respect to normal microbiota and oral health, there seem to be differences in the ability of lactobacilli isolated from caries-active or healthy subjects to inhibit Streptococcus mutans in vitro. ${ }^{10}$ In addition, the species composition of both Lactobacillus and Bifidobacterium microbiota is different between patients with periodontitis and those who are periodontally healthy. ${ }^{17,18}$ On the other hand, both lactobacilli and bifidobacteria are also associated with dental caries. ${ }^{19,20}$ In addition, caries-associated lactobacilli and bifidobacteria have been characterized as exogenous and opportunistic colonizers possibly acquired from food. ${ }^{15,21}$

During the last few years, several authors have suggested that probiotic bacteria originally planned for gut health could also be beneficial to oral health. The aim of this review is to examine potential mechanisms of probiotic bacteria in the oral cavity and to summarize observed effects of probiotics with respect to oral health. Finally, some future aspects are briefly discussed. This review focuses on probiotic lactobacilli and bifidobacteria, genera that are most used in various probiotic products.

\section{POTENTIAL MECHANISMS OF PROBIOTIC EFFECTS IN THE ORAL CAVITY}

The general mechanisms of probiotics can be divided into three main categories: normalization of the intestinal microbiota, modulation of the immune response, and metabolic effects. ${ }^{22}$ The mechanisms of probiotic action in the oral cavity could be analogous to those described for the intestine. Possible ways that probiotics might affect oral health are summarized in Figure 1. Thus far oral colonization by probiotic bacteria has often been considered essential for them to exert oral effects; however, the possibility of systemic effects cannot be excluded, although the total slgA levels in saliva seem unaffected by probiotic use. ${ }^{23,24}$ Interestingly, maternal use of some probiotic strains seems to influence the composition of breast milk. ${ }^{25}$

In respect to commensal oral microbes, several aspects support the idea that it may be possible to find bacteria that could be useful in prevention or treatment of oral diseases. In fact, it has been suggested that some observed probiotic effects are not just properties of a few well-studied strains but common to several species. ${ }^{26-28}$ The ecological plaque hypothesis suggests that selective pressure in environmental conditions can change the balance between oral health and disease. ${ }^{29}$ As bacteria can also influence their environment, and both synergistic and antagonistic interactions are suggested for bacteria in dental plaque, the environmental pressure described in the ecological plaque hypothesis could be introduced partly by bacteria. Second, it is well recognized that the normal microbiota protect the oral cavity from infections. Finally, just as there are bacterial species associated with oral diseases, there are also species that seem to be associated with oral health; ${ }^{20,30,31}$ however, it is questionable whether bacteria administered in food could influence relatively stable oral microbiota, in particular in adults. In addition, it must be kept in mind that all the mechanisms described in this section are based on in vitro results, and the clinical evidence is based mainly on short clinical pilot studies.

\section{OBSERVED EFFECTS ON}

\section{ORAL HEALTH}

\section{Caries and caries-associated microbes}

Several studies suggest that consumption of products containing probiotic lactobacilli or bifidobacteria could reduce the number of mutans streptococci in saliva. ${ }^{32-40}$ The tendency toward a decreased number of mutans streptococci in the saliva seems to be independent of the product or strain used; however, such effect has not been observed in all studies. ${ }^{41}$ The discrepancies between results cannot be explained by only the use of different probiotic strains, as different results have also been obtained using the same strains. In most of these studies, the levels of salivary lacto- 
bacilli have also been measured. With three products, an increase in the number of salivary Lactobacillus has been observed. ${ }^{33,41}$ Unfortunately, with respect to dental caries, the study groups have mainly been relatively small, and the studies fairly short. Furthermore, it is important to realize that the salivary level of caries-associated microbes does not equate to dental caries. In fact, the microbiota of unstimulated whole saliva resembles that of the tongue more than of dental plaque. ${ }^{42}$ Thus, no conclusive statement about the effects of probiotic bacteria on dental caries can be made.

\section{Periodontal diseases}

The first studies of the use of probiotics for enhancing oral health were for the treatment of periodontal inflammation. ${ }^{43}$ Patients with various periodontal diseases, gingivitis, periodontitis, and pregnancy gingivitis, were locally treated with a culture supernatant of a L. acidophilus strain. Significant recovery was reported for almost every patient. There has been significant interest in using probiotics in treatment of periodontal disease recently, too. The probiotic strains used in these studies include L. reuteri strains, L. brevis (CD2), L. casei Shirota, L. salivarius WB21, and Bacillus subtilis. L. reuteri and L. brevis have improved gingival health, as measured by decreased gum bleeding. ${ }^{44-46}$ The use of probiotic chewing gum containing L. reuteri ATCC 55730 and ATCC PTA 5289 also decreased levels of pro-inflammatory cytokines in GCF, ${ }^{46}$ and the use of L. brevis decreased MMP (collagenase) activity and other inflammatory markers in saliva. ${ }^{45}$ With $L$. casei Shirota and Bacillus subtilis no difference in test and control groups in gingival bleeding or measured plaque index was observed, but the use of L. casei Shirota decreased PMN elastase and MMP-3 activities in GCF, and gingival inflammation was lower in the group consuming the probiotic product, as measured by MPO activity after a four-day period of experimental gingivitis. ${ }^{47} \mathrm{~B}$. subtilis seemed to reduce the number of periodontal pathogens. ${ }^{48}$ Use of tablets containing L. salivarius WB21 has been shown to decrease gingival pocket depth, particularly in high-risk groups such as smokers, and

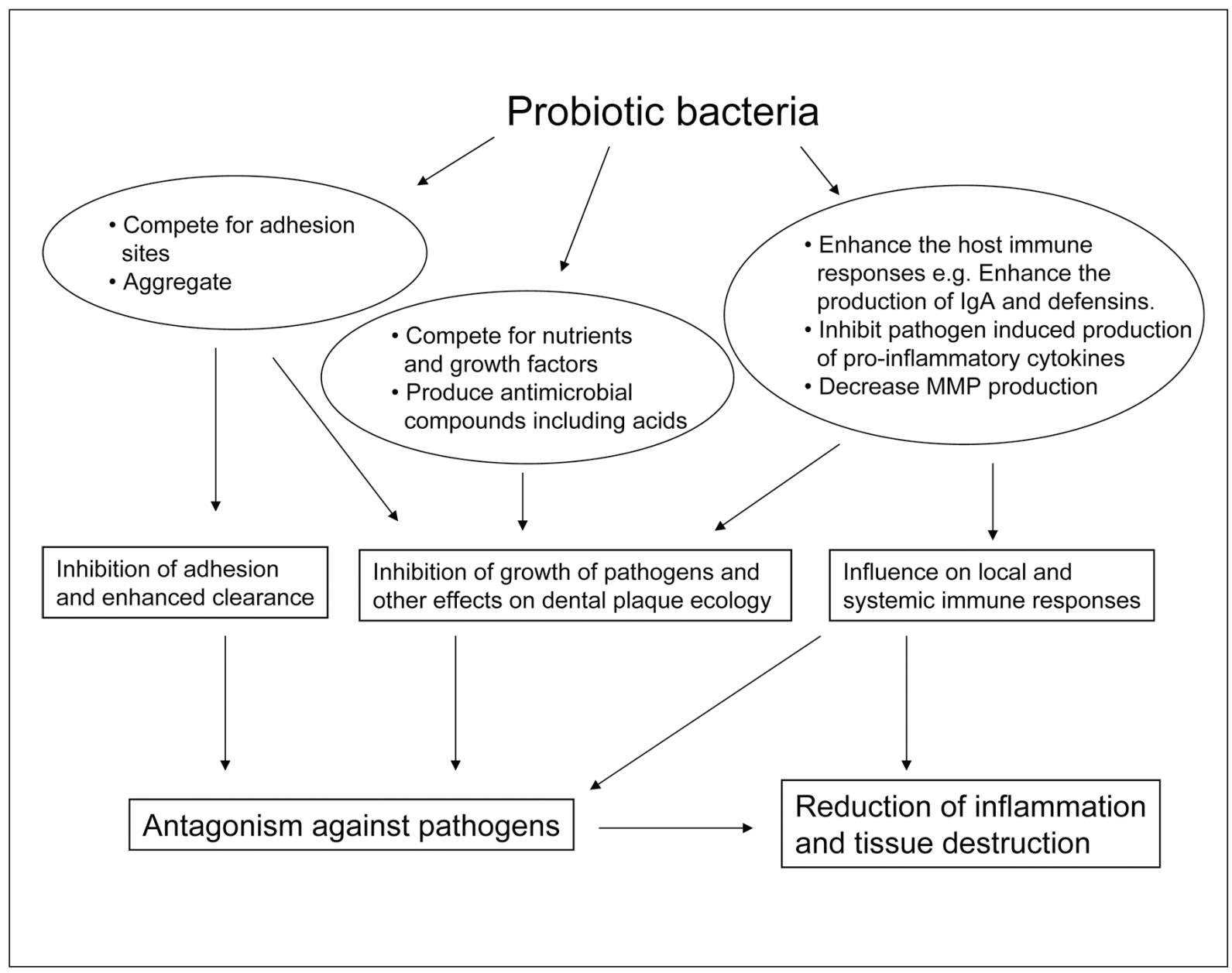

Figure 1. Potential mechanisms by which probiotic bacteria could affect oral health (Modified from ${ }^{76}$, with additional references. ${ }^{27,28,45,46,65,74,77-79}$ ). 
also affect the number of periodontopathogens in plaque. ${ }^{49,50}$ Again, although encouraging results have been observed, most studies have been fairly short. Furthermore, in some studies the observed differences were quite small, though statistically significant.

\section{Oral candida}

To the writer's knowledge, only two studies have investigated the effects of probiotic bacteria on oral Candida infection in humans. ${ }^{33,51}$ When a test group of elderly people consumed cheese containing L. rhamnosus strains GG and LC705 and Propionibacterium freudenreichii ssp. shermanii JS for 16 weeks, the number of high oral yeast counts decreased, but no changes were observed in mucosal lesions. ${ }^{51}$ In a shorter study with younger subjects, no significant difference was observed between effects of probiotic and those of control cheese on salivary Candida counts. ${ }^{33}$

\section{Halitosis}

Halitosis is not a disease but a discomfort, although some oral diseases including periodontitis may be the underlying cause; however, in approximately $90 \%$ of cases, the origin can be found in the oral cavity, ${ }^{52}$ and probiotics are marketed for the treatment of both mouth- and gut-associated halitosis. Despite that, only a few clinical studies have found different probiotic strains or products to be efficacious. The studied strains include $E$. coli Nisle 1917, S. salivarius K12, three Weissella confusa isolates, and a lactic acid-forming bacterial mixture, not specified by the authors of that work. ${ }^{53-56}$

\section{COLONIZATION AND SAFETY OF PROBIOTICS IN THE ORAL CAVITY}

Some probiotic Lactobacillus and Streptococcus strains seem able to colonize the oral cavity of some people during the time that products containing them are in active use. However, both in vitro and in vivo evidence indicate that the differences between various probiotic strains, products, and also host individuals are obvious. ${ }^{26,44,57,58}$ L. rhamnosus $\mathrm{GG}$ and two different $L$. reuteri strains have been reported to colonize the oral cavity of $48-100 \%$ of volunteers consuming products containing them. ${ }^{44,58-60}$ In addition, S. salivarius K12, used for treating oral malodor, temporarily colonizes the oral cavity for a short time after use. ${ }^{61}$
Furthermore, consumption of a mixture of seven different Lactobacillus strains increased the number of salivary Lactobacillus counts, although the identities of the strains in the saliva were not determined. ${ }^{41}$ It seems feasible that probiotic bacteria would colonize the oral cavity only when they were used in products in contact with the mouth. Indeed, Maukonen et $\mathrm{al}^{8}$ did not detect any of the probiotic bacteria administered in capsules in saliva samples. Surprisingly, consumption of capsules containing a mixture of seven different Lactobacillus strains increased the number of salivary Lactobacillus counts. ${ }^{41}$ L. reuteri ATCC 55730 l= L. reuteri SD2112) does not seem to influence the total number of salivary lactobacilli, ${ }^{36}$ but L. rhamnosus $\mathrm{GG}$ may increase it. ${ }^{33}$

Maybe because long-term colonization by probiotic bacteria is unlikely, albeit possible, ${ }^{58}$ potential adverse effects of probiotic bacteria in the oral cavity have not been a subject of much intensive research; however, probiotic products are used widely; therefore, when dental health is considered, the acidogenicity of lactobacilli and bifidobacteria cannot be overlooked. For example, one L. salivarius strain is able to induce caries in an animal model, ${ }^{62}$ and another is able to make a biofilm model more cariogenic. ${ }^{63}$

\section{FUTURE ASPECTS}

Recently, oral lactic acid bacteria and bifidobacteria have been isolated and characterized for various oral health purposes, including caries, periodontal diseases, and halitosis. 10,56,64-68 In addition, dairy strains have been studied with the aim of characterizing potential new oral probiotics; 69,70 thus, the new probiotic products targeted for oral health purposes do not necessarily comprise the same species as products now in market. Furthermore, the species might not necessarily belong only to genera Lactobacillus or Bifidobacteium. Indeed, $S$. salivarius $\mathrm{K} 12$ is used to treat oral malodor, ${ }^{55}$ and preliminary results have been published on the safety and efficacy of a probiotic mouthwash containing three different oral streptococci for reducing the number of bacteria associated with dental caries and periodontitis. ${ }^{71}$

Genetically modified microbes bring a new dimension to the concept of probiotics. One approach is to reduce the harmful properties of pathogenic strains naturally colonizing the oral 
cavity. The modified strain could then be used to replace the original pathogen. One ambitious and promising example is the generation of an $S$. mutans strain with a complete deletion of the open reading frame of lactate hydrogenase and thus significantly reduced cariogenicity. ${ }^{72}$ Another option could be to enhance the properties of a potentially beneficial strain. One example is the construction of an $L$. paracasei strain with a functional scFV (single-chain variable fragment) antibody binding to the surface of Porphyromonas gingivalis. ${ }^{73}$

Probiotics are by definition viable, and until recently the viability of probiotic bacteria was usually ascertained by culture; however, both in the intestine and in the oral cavity, a significant proportion of bacteria are not yet cultivable. In addition, bacteria in biofilms can enter a dormant state; therefore, it can be speculated that bacteria with the ability to influence the microbiota in these sites need not necessarily be culturable. There has also been debate on the definition of "viable," and even whether the definition of probiotic should be changed. Indeed, heat-killed beneficial oral Streptococcus strains have been shown to exert effects similar to those of a living bacterium. ${ }^{74}$ Furthermore, viable but nonculturable probiotic bacteria maintain properties of viable bacteria. ${ }^{75}$

\section{SUMMARY AND CONCLUSIONS}

The interest in oral probiotics has been growing during the last decades. Most of the studies have been conducted with probiotic strains originally suggested for gut health; however, it is important to realize that each of the suggested health benefits should be studied for each bacterial strain individually. Thus, a probiotic bacterium in the mouth is not necessarily an oral probiotic. Furthermore, it is quite possible that the same species are not optimal for all oral health purposes; e.g., different properties might be desired in respect to dental and gingival health.

At least some of the probiotic bacteria used in various probiotic products may colonize the oral cavity during the time they are in use; thus, the effects of probiotic bacteria in the oral cavity are important to understand. Probiotic bacteria seem to affect both oral microbiota and immune responses. On the other hand, the extent to which bacteria in food or in food ingredients can influence rela- tively stable oral microbiota is difficult to predict. Thus, both research to unravel the mechanisms of possible probiotic action and long-term clinical trials are needed if probiotics are to provide a new scientifically proven means of preventing or treating oral diseases.

Several health-promoting effects of probiotic bacteria are well documented, 2,3 and there is no reason to restrict the use of probiotic products because their effects on oral health are not yet well understood; however, their recommendation for dental health purposes is not yet justified.

\section{REFERENCES}

1. Ashwell M. Concept of functional foods. 2002; ILSI (International Life Sciences Institute) Europe, B-1200 Brussels, Belgium ISBN 1-57881-145-7

2. de Vrese M, Schrezenmeir J. Probiotics, prebiotics, and synbiotics. Adv Biochem Eng Biotechnol 2008;111:1-66.

3. Saxelin M, Tynkkynen S, Mattila-Sandholm T, de Vos WM. Probiotic and other functional microbes: from markets to mechanisms. Curr Opin Biotechnol 2005;16:204-211.

4. Busscher HJ, van Hoogmoed CG, Geertsema-Doornbusch GI, van der Kuijl-Booij M, van der Mei HC. Streptococcus thermophilus and its biosurfactants inhibit adhesion by Candida spp. on silicone rubber. Appl Environ Microbiol 1997;63:3810-3817.

5. Rodrigues L, van der Mei H, Teixeira JA, Oliveira R. Biosurfactant from Lactococcus lactis 53 inhibits microbial adhesion on silicone rubber. Appl Microbiol Biotechnol 2004;66:306-311.

6. Schwandt $L Q$, van Weissenbruch $R$, van der Mei HC, Busscher HJ, Albers FW. Effect of dairy products on the lifetime of Provox2 voice prostheses in vitro and in vivo. Head Neck 2005;27:471-477.

7. Ahrne S, Nobaek S, Jeppsson B, Adlerberth I, Wold AE, Molin G. The normal Lactobacillus flora of healthy human rectal and oral mucosa. J Appl Microbiol 1998;85:88-94.

8. Maukonen J, Mätto J, Suihko ML, Saarela M. Intra-individual diversity and similarity of salivary and faecal microbiota. J Med Microbiol 2008;57(Pt 12):1560-1568.

9. Colloca ME, Ahumada MC, Lopez ME, Nader-Macias ME. Surface properties of lactobacilli isolated from healthy subjects. Oral Dis 2000;6:227-233.

10. Simark-Mattsson C, Emilson CG, Håkansson EG, Jacobsson C, Roos K, Holm S. Lactobacillus-mediated interference of mutans streptococci in caries-free vs. cariesactive subjects. Eur J Oral Sci 2007;115:308-314.

11. Rotimi VO, Duerden BI. The development of the bacterial flora in normal neonates. J Med Microbiol 1981;14:51-62. 
12. Gueimonde M, Laitinen K, Salminen S, Isolauri E. Breast milk: a source of bifidobacteria for infant gut development and maturation? Neonatology 2007;92:64-66.

13. Abrahamsson TR, Sinkiewicz G, Jakobsson T, Fredrikson $M$, Bjorksten B. Probiotic lactobacilli in breast milk and infant stool in relation to oral intake during the first year of life. J Pediatr Gastroenterol Nutr 2009;49:349-354.

14. Crociani F, Biavati B, Alessandrini A, Chiarini C, Scardovi V. Bifidobacterium inopinatum sp. nov. and Bifidobacterium denticolens sp. nov., two new species isolated from human dental caries. Int J Syst Bacteriol 1996;46:564-571.

15. Beighton D, Gilbert SC, Clark D, Mantzourani M, AlHaboubi M, Ali F, et al. Isolation and identification of bifidobacteriaceae from human saliva. Appl Environ Microbiol 2008;74:6457-6460.

16. Metchnikoff E. Studier ofver människans natur - försök till en optimistisk filosofi, bemyndigad ofvers. från tredje franska uppl. 3th Edition. Stockholm: Isaac Marcus' boktr.aktiebolag, 1906.

17. Köll-Klais $P$, Mandar R, Leibur E, Marcotte H, Hammarstrom L, Mikelsaar M. Oral lactobacilli in chronic periodontitis and periodontal health: species composition and antimicrobial activity. Oral Microbiol Immunol 2005;20:354-361.

18. Hojo K, Mizoguchi C, Taketomo N, Ohshima T, Gomi K, Arai $T$, et al. Distribution of salivary Lactobacillus and Bifidobacterium species in periodontal health and disease. Biosci Biotechnol Biochem 2007;71:152-157.

19. Aas JA, Griffen AL, Dardis SR, Lee AM, Olsen I, Dewhirst $\mathrm{FE}$, et al. Bacteria of dental caries in primary and permanent teeth in children and young adults. J Clin Microbiol 2008;46:1407-1417.

20. Becker MR, Paster BJ, Leys EJ, Moeschberger ML, Kenyon SG, Galvin JL, et al. Molecular analysis of bacterial species associated with childhood caries. J Clin Microbiol 2002;40:1001-1009.

21. Caufield PW, Li Y, Dasanayake A, Saxena D. Diversity of lactobacilli in the oral cavities of young women with dental caries. Caries Res 2007;41:2-8.

22. Parvez S, Malik KA, Ah Kang S, Kim HY. Probiotics and their fermented food products are beneficial for health. J Appl Microbiol 2006;100:1171-1185.

23. Kekkonen RA, Lummela N, Karjalainen H, Latvala S, Tynkkynen S, Jarvenpaa $\mathrm{S}$, et al. Probiotic intervention has strain-specific anti-inflammatory effects in healthy adults. World J Gastroenterol 2008;14:2029-2036.

24. Paineau D, Carcano D, Leyer G, Darquy S, Alyanakian MA, Simoneau G, et al. Effects of seven potential probiotic strains on specific immune responses in healthy adults: a double-blind, randomized, controlled trial. FEMS Immunol Med Microbiol 2008;53:107-113.
25. Rautava S, Kalliomaki M, Isolauri E. Probiotics during pregnancy and breast-feeding might confer immunomodulatory protection against atopic disease in the infant. $J \mathrm{Al}$ lergy Clin Immunol 2002;109:119-121.

26. Haukioja A, Yli-Knuuttila H, Loimaranta V, Kari K, Ouwehand $\mathrm{AC}$, Meurman JH, et al. Oral adhesion and survival of probiotic and other lactobacilli and bifidobacteria in vitro. Oral Microbiol Immunol 2006;21:326-332.

27. Cosseau C, Devine DA, Dullaghan E, Gardy JL, Chikatamarla A, Gellatly S, et al. The commensal Streptococcus salivarius $\mathrm{K} 12$ downregulates the innate immune responses of human epithelial cells and promotes host-microbe homeostasis. Infect Immun 2008;76:4163-4175.

28. Haukioja A, Loimaranta V, Tenovuo J. Probiotic bacteria affect the composition of salivary pellicle and streptococcal adhesion in vitro. Oral Microbiol Immunol 2008;23:336-343.

29. Marsh PD. Are dental diseases examples of ecological catastrophes? Microbiology 2003;149(Pt 2):279-294.

30. Stingu CS, Eschrich K, Rodloff AC, Schaumann R, Jentsch $\mathrm{H}$. Periodontitis is associated with a loss of colonization by Streptococcus sanguinis. J Med Microbiol 2008;57(Pt 4):495-499.

31. Riep B, Edesi-Neuss L, Claessen F, Skarabis H, Ehmke B, Flemmig TF, et al. Are putative periodontal pathogens reliable diagnostic markers? J Clin Microbiol 2009;47:17051711.

32. Näse L, Hatakka K, Savilahti E, Saxelin M, Ponka A, Poussa $T$, et al. Effect of long-term consumption of a probiotic bacterium, Lactobacillus rhamnosus $G G$, in milk on dental caries and caries risk in children. Caries Res 2001;35:412420.

33. Ahola AJ, Yli-Knuuttila H, Suomalainen T, Poussa T, Ahlstrom A, Meurman JH, et al. Short-term consumption of probiotic-containing cheese and its effect on dental caries risk factors. Arch Oral Biol 2002;47:799-804.

34. Nikawa H, Makihira S, Fukushima H, Nishimura H, Ozaki $\mathrm{Y}$, Ishida $\mathrm{K}$, et al. Lactobacillus reuteri in bovine milk fermented decreases the oral carriage of mutans streptococci. Int J Food Microbiol 2004;95:219-223.

35. Caglar E, Sandalli N, Twetman S, Kavaloglu S, Ergeneli S, Selvi S. Effect of youghurt with Bifidobacterium DN-173 010 on salivary mutans streptococci and lactobacilli in young adults. Acta Odont Scand 2005;63:317-320.

36. Caglar E, Cildir SK, Ergeneli S, Sandalli N, Twetman S. Salivary mutans streptococci and lactobacilli levels after ingestion of the probiotic bacterium Lactobacillus reuteri ATCC 55730 by straws or tablets. Acta Odontol Scand 2006;64:314-318. 
37. Caglar E, Kavaloglu SC, Kuscu 00, Sandalli N, Holgerson $\mathrm{PL}$, Twetman S. Effect of chewing gums containing xylitol or probiotic bacteria on salivary mutans streptococci and lactobacilli. Clin Oral Investig 2007;11:425-429.

38. Caglar E, Kuscu 00, Selvi Kuvvetli S, Kavaloglu Cildir S, Sandalli N, Twetman S. Short-term effect of ice-cream containing Bifidobacterium lactis $\mathrm{Bb}-12$ on the number of salivary mutans streptococci and lactobacilli. Acta Odontol Scand 2008;66:154-158.

39. Caglar E, Kuscu 00, Cildir SK, Kuvvetli SS, Sandalli N. A probiotic lozenge administered medical device and its effect on salivary mutans streptococci and lactobacilli. Int $J$ Paediatr Dent 2008;18:35-39.

40. Cildir SK, Germec D, Sandalli N, Ozdemir FI, Arun T, Twetman $\mathrm{S}$, et al. Reduction of salivary mutans streptococci in orthodontic patients during daily consumption of yoghurt containing probiotic bacteria. Eur J Orthod 2009;31:4074011.

41. Montalto M, Vastola M, Marigo L, Covino M, Graziosetto R, Curigliano $V$, et al. Probiotic treatment increases salivary counts of lactobacilli: a double-blind, randomized, controlled study. Digestion 2004;69:53-56.

42. Mager DL, Ximenez-Fyvie LA, Haffajee AD, Socransky SS. Distribution of selected bacterial species on intraoral surfaces. J Clin Periodontol 2003;30:644-654.

43. Kragen $\mathrm{H}$. The treatment of inflammatory affections of the oral mucosa with a lactic acid bacterial culture preparation. Zahnarztl Welt 1954;9:306-308.

44. Krasse P, Carlsson B, Dahl C, Paulsson A, Nilsson A, Sinkiewicz $G$. Decreased gum bleeding and reduced gingivitis by the probiotic Lactobacillus reuteri. Swed Dent $J$ 2006;30:55-60.

45. Della Riccia DN, Bizzini F, Perilli MG, Polimeni A, Trinchieri $V$, Amicosante $G$, et al. Anti-inflammatory effects of Lactobacillus brevis (CD2) on periodontal disease. Oral Dis 2007;13:376-385.

46. Twetman S, Derawi B, Keller M, Ekstrand K, Yucel-Lindberg $T$, Stecksen-Blicks $C$. Short-term effect of chewing gums containing probiotic Lactobacillus reuteri on the levels of inflammatory mediators in gingival crevicular fluid. Acta Odontol Scand 2009;67:19-24.

47. Staab B, Eick S, Knofler G, Jentsch $H$. The influence of a probiotic milk drink on the development of gingivitis: a pilot study. J Clin Periodontol 2009;36:850-856.

48. Tsubura S, Mizunuma H, Ishikawa S, Oyake I, Okabayashi M, Katoh $\mathrm{K}$, et al. The effect of Bacillus subtilis mouth rinsing in patients with periodontitis. Eur J Clin Microbiol Infect Dis 2009;28:1353-1356.
49. Shimauchi H, Mayanagi G, Nakaya S, Minamibuchi M, Ito $Y$, Yamaki K, et al. Improvement of periodontal condition by probiotics with Lactobacillus salivarius WB21: a randomized, double-blind, placebo-controlled study. J Clin Periodontol 2008;35:897-905.

50. Mayanagi G, Kimura M, Nakaya S, Hirata H, Sakamoto M, Benno Y, et al. Probiotic effects of orally administered Lactobacillus salivarius WB21-containing tablets on periodontopathic bacteria: a double-blinded, placebo-controlled, randomized clinical trial. J Clin Periodontol 2009;36:506513.

51. Hatakka K, Ahola AJ, Yli-Knuuttila H, Richardson M, Poussa T, Meurman JH, et al. Probiotics reduce the prevalence of oral candida in the elderly-a randomized controlled trial. J Dent Res 2007;86:125-130.

52. Delanghe G, Ghyselen J, van Steenberghe D, Feenstra L. Multidisciplinary breath-odour clinic. The Lancet 1997;350:187-187.

53. Henker J, Schuster F, Nissler K. Successful treatment of gut-caused halitosis with a suspension of living non-pathogenic Escherichia coli bacteria-a case report. Eur J Pediatr 2001;160:592-594.

54. Iwanicka-Grzegorek K, Lipkowska E, Kepa J, Michalik J, Wierzbicka M. Comparison of ninhydrin method of detecting amine compounds with other methods of halitosis detection. Oral Dis 2005;11 Suppl 1:37-39.

55. Burton JP, Chilcott CN, Moore CJ, Speiser G, Tagg JR. A preliminary study of the effect of probiotic Streptococcus salivarius K12 on oral malodour parameters. J Appl Microbiol 2006;100:754-764.

56. Kang MS, Kim BG, Chung J, Lee HC, Oh JS. Inhibitory effect of Weissella cibaria isolates on the production of volatile sulphur compounds. J Clin Periodontol 2006;33:226-232.

57. Busscher HJ, Mulder AF, van der Mei HC. In vitro adhesion to enamel and in vivo colonization of tooth surfaces by lactobacilli from a bio-yoghurt. Caries Res 1999;33:403-404.

58. Yli-Knuuttila H, Snall J, Kari K, Meurman JH. Colonization of Lactobacillus rhamnosus GG in the oral cavity. Oral Microbiol Immunol 2006;21:129-131.

59. Meurman JH, Antila H, Salminen S. Recovery of Lactobacillus Strain GG (ATCC 53103) from saliva of healthy volunteers after consumption of yoghurt prepared with the bacterium. Microbial Ecology in Health and Disease 1994; 7:295-298.

60. Caglar E, Topcuoglu N, Cildir SK, Sandalli N, Kulekci G. Oral colonization by Lactobacillus reuteri ATCC 55730 after exposure to probiotics. Int J Paediatr Dent 2009;19:377-381.

61. Horz HP, Meinelt A, Houben B, Conrads G. Distribution and persistence of probiotic Streptococcus salivarius K12 in the human oral cavity as determined by real-time quantitative polymerase chain reaction. Oral Microbiol Immunol 2007;22:126-130. 
62. Matsumoto M, Tsuji M, Sasaki H, Fujita K, Nomura R, Nakano K, et al. Cariogenicity of the probiotic bacterium Lactobacillus salivarius in rats. Caries Res 2005;39:479-483.

63. Pham LC, van Spanning RJ, Roling WF, Prosperi AC, Terefework Z, Ten Cate JM, et al. Effects of probiotic Lactobacillus salivarius W24 on the compositional stability of oral microbial communities. Arch Oral Biol 2009;54:132137.

64. Sookkhee S, Chulasiri M, Prachyabrued W. Lactic acid bacteria from healthy oral cavity of Thai volunteers: inhibition of oral pathogens. J Appl Microbiol 2001;90:172-179.

65. Kang MS, Na HS, Oh JS. Coaggregation ability of Weissella cibaria isolates with Fusobacterium nucleatum and their adhesiveness to epithelial cells. FEMS Microbiol Lett 2005;253:323-329.

66. Kang MS, Chung J, Kim SM, Yang KH, Oh JS. Effect of Weissella cibaria isolates on the formation of Streptococcus mutans biofilm. Caries Res 2006;40:418-425.

67. Strahinic I, Busarcevic M, Pavlica D, Milasin J, Golic N, Topisirovic L. Molecular and biochemical characterizations of human oral lactobacilli as putative probiotic candidates. Oral Microbiol Immunol 2007;22:111-117.

68. Koll P, Mandar R, Marcotte H, Leibur E, Mikelsaar M, Hammarstrom L. Characterization of oral lactobacilli as potential probiotics for oral health. Oral Microbiol Immunol 2008;23:139-147.

69. Comelli EM, Guggenheim B, Stingele F, Neeser JR. Selection of dairy bacterial strains as probiotics for oral health. Eur J Oral Sci 2002;110:218-224.

70. Stamatova I, Kari K, Vladimirov S, Meurman JH. In vitro evaluation of yoghurt starter lactobacilli and Lactobacillus rhamnosus GG adhesion to saliva-coated surfaces. Oral Microbiol Immunol 2009;24:218-223.

71. Zahradnik RT, Magnusson I, Walker C, McDonell E, Hillman $\mathrm{CH}$, Hillman JD. Preliminary assessment of safety and effectiveness in humans of ProBiora3, a probiotic mouthwash. J Appl Microbiol 2009;107:682-690.

72. Hillman JD, Mo J, McDonell E, Cvitkovitch D, Hillman CH. Modification of an effector strain for replacement therapy of dental caries to enable clinical safety trials. J Appl Microbiol 2007;102:1209-1219.

73. Marcotte H, Koll-Klais P, Hultberg A, Zhao Y, Gmur R, Mandar $\mathrm{R}$, et al. Expression of single-chain antibody against RgpA protease of Porphyromonas gingivalis in Lactobacillus. J Appl Microbiol 2006;100:256-263.

74. Sliepen I, Van Damme J, Van Essche M, Loozen G, Quirynen $M$, Teughels W. Microbial interactions influence inflammatory host cell responses. J Dent Res 2009;88:1026-1030.
75. Lahtinen SJ, Ahokoski H, Reinikainen JP, Gueimonde M, Nurmi J, Ouwehand AC, et al. Degradation of 16S rRNA and attributes of viability of viable but nonculturable probiotic bacteria. Lett Appl Microbiol 2008;46:693-698.

76. Hatakka K, Saxelin M. Probiotics in intestinal and non-intestinal infectious diseases--clinical evidence. Curr Pharm Des 2008;14:1351-1367.

77. Twetman L, Larsen U, Fiehn NE, Stecksen-Blicks C, Twetman S. Coaggregation between probiotic bacteria and caries-associated strains: An in vitro study. Acta Odontol Scand 2009;27:1-5

78. Boirivant $M$, Strober $W$. The mechanism of action of probiotics. Curr Opin Gastroenterol 2007;23:679-692.

79. Hojo K, Nagaoka S, Murata S, Taketomo N, Ohshima T, Maeda N. Reduction of vitamin K concentration by salivary Bifidobacterium strains and their possible nutritional competition with Porphyromonas gingivalis. J Appl Microbiol 2007;103:1969-1974. 